\title{
Effect of CST Ion Exchange Loading on the Volume of Glass Produced During the Vitrification Demonstration at SRTC (U)
}

by

M. K. Andrews

Westinghouse Savannah River Company

Savannah River Site

Aiken, South Carolina 29808

J. R. Harbour

DISTRIBUTION OF THIS DOCUMENT IS UNLIMITED

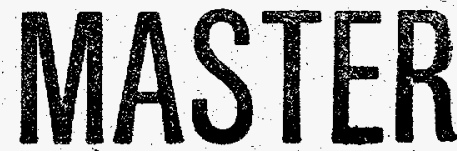

DOE Contract No. DE-AC09-96SR18500

This paper was prepared in connection with work done under the above contract number with the U. S.

Department of Energy. By acceptance of this paper, the publisher and/or recipient acknowledges the U.S. Government's right to retain a nonexclusive, royalty-free license in and to any copyright covering this paper, along with the right to reproduce and to authorize others to reproduce all or part of the copyrighted paper. 


\section{DISCLAMMER}

Portions of this document may be illegible in electronic image products. Images are produced from the best available original document. 


\section{DISCLAIMER}

This report was prepared as an account of work sponsored by an agency of the United States Government. Neither the United States Government nor any agency thereof, nor any of their employees, makes any warranty, express or implied, or assumes any legal liability or responsibility for the accuracy, completeness, or usefulness of any information, apparatus, product, or process disclosed, or represents that its use would not infringe privately owned rights. Reference herein to any specific commercial product, process, or service by trade name, trademark, manufacturer, or otherwise does not necessarily constitute or imply its endorsement, recommendation, or favoring by the United States Government or any agency thereof. The views and opinions of authors expressed herein do not necessarily state or reflect those of the United States Government or any agency thereof.

This report has been reproduced directly from the best available copy.

Available to DOE and DOE contractors from the Office of Scientific and Technical Information, P.O. Box 62, Oak Ridge, TN 37831; prices available from (615) 576-8401.

Available to the public from the National Technical Information Service, U.S. Department of Commerce, 5285 Port Royal Road, Springfield, VA 22161. 


\section{EFFECT OF CST ION EXCHANGE LOADING ON THE VOLUME OF GLASS PRODUCED DURING THE VITRIFICATION DEMONSTRATION AT SRTC}

M. K. Andrews and J. R. Harbour

\section{INTRODUCTION}

Oak Ridge National Laboratory (ORNL) and SRTC have a joint project in which 25,000 gallons of supernate waste from the Melton Valley storage Tanks at Oak Ridge (OR) will be treated by passage through a crystalline silicotitanate (CST) ion exchange medium.1 The CST was designed to sorb cesium, the primary radionuclide $(\mathrm{Cs}-137)$ in the supernate of the Melton Valley tanks. A smaller amount of strontium will also be sorbed. At least one drum of the loaded sorbent will then be shipped to SRTC where it will be mixed with glass formers and fed as an aqueous slurry to an $1150^{\circ} \mathrm{C}$ joule-heated melter within the SRTC Shielded Cells. The molten glass will be poured into $500 \mathrm{ml}$ stainless steel beakers. The original plan was to place the $500 \mathrm{ml}$ beakers in 30 gallon drums for shipment to and disposal at the Nevada Test Site (NTS). A recent scope change included provisions to dispose of the vitrified waste at SRS. This report addresses requirements for disposal at either NTS or SRS.

The number of $500 \mathrm{ml}$ stainless steel beakers which will be filled during the ion exchange sorbent vitrification demonstration will be dependent upon (1) the amount of loaded sorbent received from ORNL, (2) the CST loading in the glass matrix, and (3) possibly upon the amount of radioactive cesium and strontium sorbed on the CST. The CST loading within the glass is dependent upon development of a glass formulation which will produce a waste form which meets the Waste Acceptance Criteria (WAC) of the Nevada Test Site 
(NTS) 2 and has properties (viscosity, liquidus, and redox) compatible with vitrification processing within the shielded Cells.

Glass formulation has been an ongoing effort for this project and is currently being fine tuned. 3 The composition of the glass formers (frit) has been disclosed (M. K. Andrews, $R$. $J$. Workman, and J. C. Marra) to the Patent Department for consideration as a patent. current efforts on the formulation relate to a determination of the upper limit of CST loading within the glass while still maintaining acceptable durability, RCRA metal release, melt viscosity, and liquidus. As discussed below, if the vitrified waste would be shipped to NTS, the maximum CST loading may be bounded by the Class C limit for curie content.

\section{AMOUNT OF CST FROM ORNL}

The amount of CST which will be received from ORNL is uncertain but can be estimated. For this paper, two different values were used. The first value was the total amount expected to be sent based on results from ORNL's small scale radioactive testing, while the second value was the expected amount of CST under the recently revised scope.

Value \#1: Estimate from Radioactive Testing (266 liters).

Results from recent small scale radioactive testing at ORNL with supernate from tanks $\mathrm{W}-27$ and $\mathrm{W}-29$ have indicated that the CST is performing better than originally estimated.

Therefore, less sorbent will be necessary to treat the 25,000 gallons of supernate. This leads to an estimate of 7 columns or 70 gallons of CST, corresponding to -38 liters of CST sorbent per column, for a total of 266 liters CST sorbent for the 7 columns. The small scale testing also indicated that each drum would contain between 175 and 220 curies. At 10 gallons of sorbent per drum and using the conservative estimate of $220 \mathrm{Ci}$, the amount of radioactivity is estimated at $5810 \mathrm{Ci} / \mathrm{m}^{3}$ of $\mathrm{CST}$.

Value \#2: Expected Amount with Revised Scope (38 1iters). The loaded sorbent will be obtained by passing up to 25,000 gallons of supernate from a blend of OR tanks $W-27$ and $W-29$ through columns containing the CST. The loaded sorbent will be dried and then shipped in 30 gallon drums to SRTC. The recent change in scope calls for only the initial drum of sorbent to be shipped to SRTC. The drum will contain approximately 10 gallons, or 38 liters, of CST. With a bulk density of $1.0 \mathrm{~g} / \mathrm{CC}$, this corresponds to $38 \mathrm{~kg}$ of CST. This first column of CST will not be fully loaded, so it was estimated that the drum would contain -25 Curies, corresponding to a total radioactivity of $658 \mathrm{Ci} / \mathrm{m}^{3}$. 


\section{LOADING OF RADIONUCLIDES ON CST}

If the vitrified waste is shipped to NTS, the Curie content in the glass must be less than $4600 \mathrm{Ci} / \mathrm{m}^{3}$ to ensure that the limits set for Class $C$ waste are not exceeded. 2 Since this Curie limit is based on volume, it is necessary that the density of the glass waste form be known as a function of CST loading. The glass densities at various CST loadings for the formulation developed for the CST are provided in Table 1.3 (Not all of the glasses produced were acceptable glasses and the density for the 70 wt: CST glass was obtained by extrapolation.)

Using these densities and CST Value \#1 (266 liters), the Curies $/ \mathrm{m}^{3}$ of $\mathrm{glass}$ were calculated for various waste loadings. These data are included in Table 1 and plotted in Figure 1. From Table 1, the $4600 \mathrm{Ci} / \mathrm{m}^{3}$ limit is reached at a waste loading of $\sim 29$ wt\%.

Table 1 - Measured Densities $\left(\mathrm{g} / \mathrm{cm}^{3}\right)$ of CST-Loaded Glasses and Curie Loading of the Waste Glass based on 220 Cuxies/Drum (The 70 wt\% loading was obtained by extrapolation.)

\begin{tabular}{lcc} 
CST & $\begin{array}{c}\text { Glass } \\
\text { Density }\end{array}$ & $\begin{array}{c}\text { (220 Ci/drum } \\
\text { wto }\end{array}$ \\
\hline 10 & 2.57 & $\frac{\mathrm{Ci} / \mathrm{m}^{3}}{1500}$ \\
15 & 2.59 & 2264 \\
20 & 2.65 & 3082 \\
25 & 2.68 & 3901 \\
30 & 2.71 & 4719 \\
40 & 2.83 & 6574 \\
45 & 2.85 & 7447 \\
50 & 2.90 & 8430 \\
60 & 3.02 & 10530 \\
70 & 3.05 & 12410
\end{tabular}

Under the reduced scope, the CST sorbent sent to SRTC will not be fully loaded. Based on $25 \mathrm{Ci} /$ drum, the Curie loadings in the glass were calculated as a function of CST waste loading. These calculations are provided in Table 2 . Glasses with waste loadings of greater than 70 wt\% CST will not exceed the Class C Iimit. 
Figure 1 - Curies/m3 as a function of CST Loading

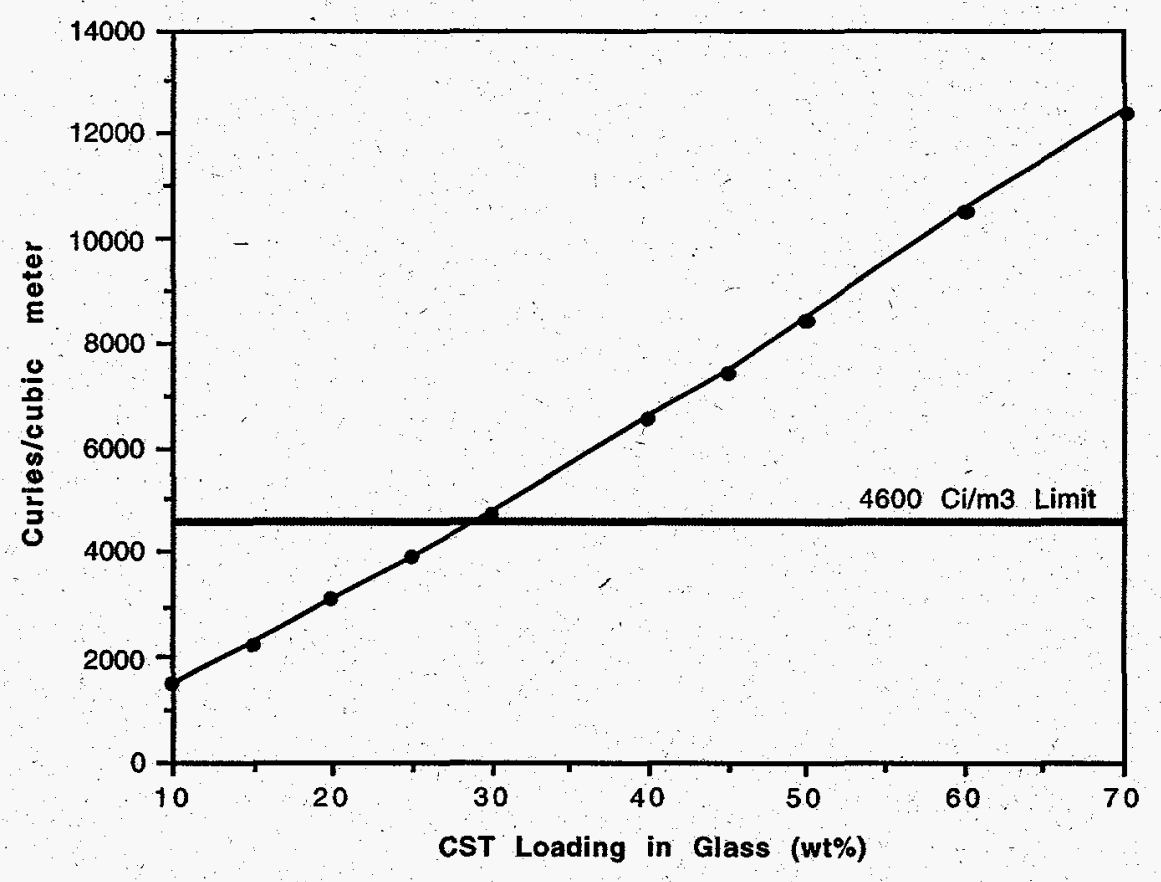

Table 2 - Measured Densities $\left(\mathrm{g} / \mathrm{cm}^{3}\right)$ of CST-Loaded Glasses and Curie Loading of the Waste Glass based on 25 Curies/Drum (The 70 wt\% loading was obtained by extrapolation.)

\begin{tabular}{ccc} 
CST & Glass & e25 $\mathrm{Ci} /$ drum \\
wto & $\frac{\mathrm{Ci} / \mathrm{m}^{3}}{170}$ \\
\hline 10 & 2.57 & 170 \\
15 & 2.59 & 257 \\
20 & 2.65 & 350 \\
25 & 2.68 & 443 \\
30 & 2.71 & 536 \\
40 & 2.83 & 747 \\
45 & 2.85 & 846 \\
50 & 2.90 & 958 \\
60 & 3.02 & 1197 \\
70 & 3.05 & 1410
\end{tabular}

\section{GLASS FORMULATION AND WASTE LOADING}

SRTC efforts have demonstrated that $\sim 40$ wt: CST loading in glass can be achieved producing a durable glass as measured by the PCT protocol. (The original goal for this project was to obtain a 20 wt: CST loading in the glass.) Additional durability, viscosity, liquidus, and redox properties are being obtained on glasses in the range of 40 to 60 wt: CST loadings in order to establish the maximum waste loading which will still produce an acceptable waste form. 
The number of beakers of glass produced depends significantly on the waste loading. Table 3 presents the number of beakers produced as a function of the waste loading. If the vitrified waste was shipped to NTS, the beakers would be placed into 30 gallon drums. A rack has been designed that will accommodate 90 beakers in each drum. As a reference, the number of drums that would be required to ship the beakers for disposal is also included in Table 3 . In these calculations, Value \#1, the amount of CST expected to be used by ORNL ( 266 liters), was used. Table 4 presents the same information using value \#2 (38 1iters).

Table 3 - Number of $500 \mathrm{ml}$ Beakers Filled and 30 Gallon Drums and Fill Time Required as a Function of the CST Loading in the Glass (266. liters of CST)

\begin{tabular}{ccccc} 
CST & $\begin{array}{c}\text { Glass } \\
\text { wt: }\end{array}$ & $\begin{array}{c}\text { Number } \\
\text { Density }\end{array}$ & $\begin{array}{c}\text { Number of } \\
\text { drums }\end{array}$ & $\begin{array}{c}\text { Fill } \\
2,060\end{array}$ \\
\hline 10 & 2.57 & $\frac{23}{\text { Time (days) }}$ & 342 \\
15 & 2.59 & 1,365 & 16 & 228 \\
20 & 2.65 & 1,000 & 12 & 166 \\
25 & 2.68 & 790 & 9 & 138 \\
30 & 2.71 & 650 & 8 & 108 \\
40 & 2.83 & 470 & 6 & 78 \\
45 & 2.85 & 415 & 5 & 70 \\
50 & 2.90 & 365 & 4 & 62 \\
60 & 3.02 & 290 & 4 & 48 \\
70 & 3.05 & 245 & 3 & 42
\end{tabular}

From previous experience, the fill time per $500 \mathrm{ml}$ beaker is estimated to be 2 hours. That is roughly 0.7 pounds per hour. Using this value and an estimated 50\% attainment rate, the total time for vitrifying the 266 liters of CST was estimated for each loading and the results included in Table 3. Since an extended vitrification demonstration has not been performed, the actual attainment rate is uncertain. Clearly, the fill time for the demonstration will depend significantly on the throughput of the melter (pounds of glass/hour). If throughput can be increased, there will be a reduction in the overall fill time and conversely, a smaller throughput will extend the time for the overall demonstration.

Based on the recent scope changes, the calculations presented in Table 4 provide a more realistic estimate of the number of beakers and the fill time. (Table 4 uses the CST value \#2 of 38 Iiters.) A comparison of the required fill times for CST Values \#1 and \#2 is presented graphically in Figure 2. 
Table 4 - Number of $500 \mathrm{ml}$ Beakers Filled and Fill Time Required as a Function of the CST Loading in the Glass (38 liters of CST)

\begin{tabular}{|c|c|c|c|}
\hline $\begin{array}{l}\text { CST } \\
\text { wt\% }\end{array}$ & $\begin{array}{l}\text { Glass } \\
\text { Density }\end{array}$ & $\begin{array}{l}\text { Number } \\
\text { Beakers }\end{array}$ & $\begin{array}{c}\text { Fill } \\
\text { Time (days) }\end{array}$ \\
\hline 10 & 2.57 & 295 & 50 \\
\hline 15 & 2.59 & 195 & 33 \\
\hline 20 & 2.65 & 143 & 24 \\
\hline 25 & 2.68 & 113 & 19 \\
\hline 30 & 2.71 & 93 & 16 \\
\hline 40 & 2.83 & 67 & 12 \\
\hline 45 & 2.85 & 60 & 10 \\
\hline 50 & 2.90 & 52 & 9 \\
\hline 60 & 3.02 & 41 & 7 \\
\hline 7.0 & 3.05 & 35 & 6 \\
\hline
\end{tabular}

Figure 2 - Fill time required as a function of CST Loading (at $50 \%$ attainment)

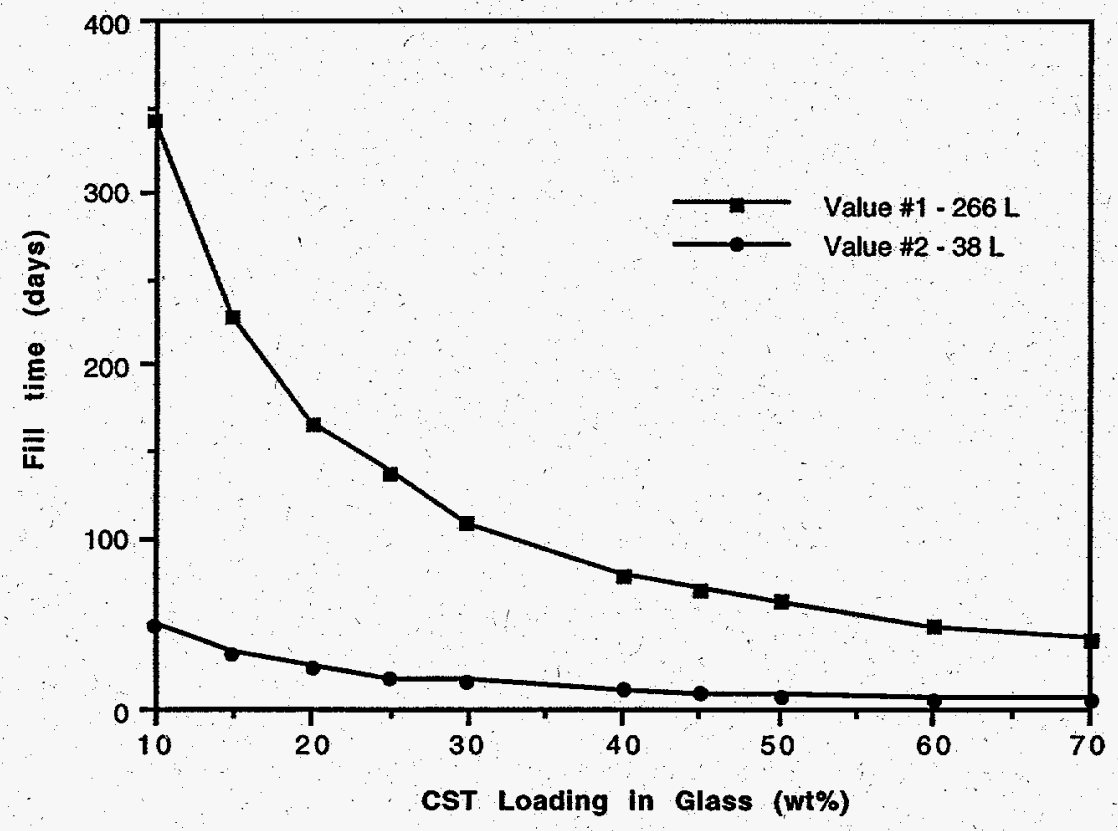

The importance of CST loading is evident from this data. For Value \#1 and the original goal of $20 \mathrm{wt} \%$ CST, the overall. minimum time for vitrification is 166 days. Increasing the loading to 40 wt: CST decreases this minimum time to 78 days. The increase in CST loading from 20 to 40 wt $\%$ reduces the total amount of waste from 500 liters $(1325 \mathrm{~kg})$ to 235 liters $(665 \mathrm{~kg})$.

For Value \#2, the original 20 wt? CST loading would require. 24 days, versus the 12 days time for vitrification at 40 wt: loading. The increase in CST loading from 20 to 40 wt\% 
reduces the total amount of waste produced from 72 liters $(190 \mathrm{~kg})$ to 34 liters $(95 \mathrm{~kg})$.

The importance of maximizing the CST loading is also evident from Tables 3 and 4 . For Value \#1 the increase from 40 to 50 wt: loading corresponds to a reduction of 16 days at $50 \%$ attainment. For Value \#2, the increase from 40 to 50 wt\% loading corresponds to a reduction of 3 days at $50 \%$ attainment. The ongoing formulation work is focusing on the maximum loading of CST while still producing a durable and processable glass However, in order for the higher waste loadings and corresponding savings to be realized for value \#1, the Nevada Test site (NTS) would have to accept waste with a Curie loading greater than the class C limit.

\section{SUMMARY}

The volume of glass produced during the vitrification demonstration of cesium-137. loaded CST sorbent is highly dependent on the loading of the CST within the borosilicate glass. Using the maximum amount of CST that could be received (Value \#1 of 266 liters), a waste loading of 20 wt\% CST would result in the production of 1000 stainless steel beakers $(500 \mathrm{ml}$ each) and would require 12 thirty-gallon drums if the waste was transported to NTS for disposal. The time for the demonstration at 50\% attainment would be 166 days. The recent formulation development indicates that at least 40 wto CST loading may be possible. This loading would result in a significant reduction to 470 beakers and 6 drums and an overall time of 78 days at $50 \%$ attainment. The increase in CST loading from 20 to 40 wt\% reduces the total amount of waste from 500 liters $(1325 \mathrm{~kg})$ to 235 liters $(665$ $\mathrm{kg})$.

The corresponding numbers for Value \#2 (38 liters of CST) are also significant. The original goal of a 20 wt: CST loading would result in the production of 143 stainless steel beakers $(500 \mathrm{ml}$ each). The time for the demonstration at $50 \%$ attainment would be 24 days. At 40 wto CST loading, the waste is reduced to 67 , beakers and 6 drums and to an overall time at 50\% attainment of 12 days. This increase in CST loading from 20 to 40 wt $\%$ reduces the total amount of waste from 72 liters $(190 \mathrm{~kg})$ to 34 liters $(95 \mathrm{~kg})$.

Current efforts in formulation experimentation will define the CST loading for the demonstration. The glass waste form must meet durability requirements, RCRA metal release limits, and viscosity, liquidus, and redox requirements for processing. As indicated, higher waste loadings will reduce the processing time required, thus, reducing the overall costs. An added benefit, of course, is the reduction of total waste volume provided by higher loadings, leading to less waste disposal. 


\section{REFERENCES}

1. D. M. Ferrara, Immobilization of IX Resins (CST), WSRC Immobilization, TTP SR16WT31, Waste Tanks Immobilization, Task Number B, October, 1996.

2. Nevada Test Site Waste Acceptance Criteria, NTSWAC, Rev. 0, September, 1996.

3. D. M. Ferrara, M. K. Andrews, and J. R. Harbour, Fiscal Year 1996 Report on Vitrification of CesiumLoaded Crystaline silicotitanate (U), WSRC-TR-960314, October 1996. 